"This is an Accepted Manuscript of an article published by Taylor \& Francis in Information \& Communications Technology Law, 24:3, 242261, on 18 September 2015, available online: https://doi.org/10.1080/13600834.2015.1084679 


\title{
Access to Medicines and the TRIPS Agreement: What Next for Sub-Saharan Africa?
}

\begin{abstract}
Jae Sundaram*
When the trade ministers signed the TRIPS agreement in Marrakesh in the spring of 1994, they were in effect signing the death warrants on thousands of people in sub-Saharan Africa and elsewhere in the developing countries. This is one of the reasons that TRIPS has generated such immense concern. - JE Stiglitz ${ }^{1}$
\end{abstract}

\begin{abstract}
When the proposal for an international intellectual property (IP) rights protection was included as an item in the agenda for negotiation in the Uruguay Round of World Trade Organization negotiations, it was strongly opposed by developing countries including Brazil, India, Argentina and others. The developing countries and least developed countries (LDCs) from Africa, realising the difficulties the Agreement would put them in, had vigorously campaigned against the inclusion of IP rights protection within the multilateral trading system. One of the chief areas of concern for the developing countries and LDCs was the difficulty of accessing affordable medicines under the Agreement on Trade-Related Intellectual Property Rights (TRIPS) regime. While the resistance was gradually eroded and eventually neutralised during the long drawn Uruguay Round of Negotiations, the developing countries and the LDCs gained a few concessions in the post-TRIPS era in the form of Doha Declaration, which in their opinion would have given them the opportunity to invoke the emergency provisions of the Agreement in times of need to access essential medicines for their citizens. This was not to be the case, as the ground realities were difficult to manoeuvre and there were more impediments to invoking the flexibilities than originally perceived. This article will suggest that the best option available for sub-Saharan Africa is seeking an outright amendment of the TRIPS Agreement, as working within the parameters of the Agreement to achieve the goal of access to affordable medicines is not a viable option. It will also be argued that unless it acts urgently to seek the amendment it may be too late, as it could find itself left behind by both developing countries from other continents and patent holding developed countries alike.
\end{abstract}

Keywords: TRIPS-Agreement; Africa; Access-to-Medicines; AIDS/HIV; Generics

\section{Introduction: Negotiations}

This article takes up for analysis the continued problems faced in access to medicines in sub-Saharan Africa in the post-TRIPS (The Agreement on Trade-Related Aspects of Intellectual Property Rights) era, and the way forward. It is well documented that the African countries along with developing countries from other continents were opposed to the introduction of an IP protection even during the Uruguay Round of Negotiations; the proposal went ahead, regardless of the oppositions, resulting in the introduction of the TRIPS Agreement. The articles studies the reasons behind the continued inability of the sub-Saharan African States in accessing affordable medicines, the difficulty or failure of sub-Saharan African countries to utilise flexibilities found in the TRIPS agreement, and also raise the inevitable question as to what is keeping the sub-Saharan African countries from seeking an amendment of the TRIPS Agreement to remove pharmaceutical patents from the ambit of its

\footnotetext{
*Senior Lecturer in Law, Law School, University of Buckingham. Email: jae.sundaram@buckingham.ac.uk.

${ }^{1}$ JE Stiglitz, 'Economic Foundations of Intellectual Property Rights' Duke Law Journal Vol. 57 (2008) 1693$1724,1701$.
} 
operation. This article is divided into three parts, with the first part presenting the entry of the TRIPS Agreement, the flexibilities, the introduction of Doha Declaration in later years, and the continuing problems faced by sub-Saharan African countries with regard to access to medicines, the second part providing the background to the current state of affairs as regards access to medicines in sub-Saharan Africa and the measures taken to find solutions. The second part will also identify the factors contributing to the continued failure of the sub-Saharan African countries to find a viable solution to the problems. The third part will focus on discussing the findings and suggesting the way forward to arrive at a permanent solution to counter the shortcomings of TRIPS Agreement and the consequent problems.

\section{TRIPS Agreement: Troubled Passage and Entry}

The Agreement on Trade-Related Aspects of Intellectual Property Rights (TRIPS) is viewed as the most significant agreements to emerge out of the Uruguay Round of Negotiations ${ }^{2}$ and yet controversial of the covered agreements of the World Trade Organization (WTO). The TRIPS Agreement, which addresses a range of IP rights issues and mandates a global minimum standard for IP rights protection on all member countries, was drafted at the behest of patent rights holding developed countries. ${ }^{3}$ It has far-reaching implications on international intellectual property rights protection and access to medicines in developing countries and LDCs. The expression 'access to medicines,' although widely used, does not have a standard definition. The main reason the Agreement is considered as a serious threat to access to medicines is that the 20 -year product patent protection introduced through the Agreement covers pharmaceutical patents, ${ }^{4}$ and also outlaws process patents. Process patent, as opposed to product patent paved the way for affordable generic drugs and is much more affordable than patented/brand name drugs produced by transnational pharmaceutical corporations. ${ }^{5}$ Interestingly, most sub-Saharan African countries rely on generic drugs, ${ }^{6}$ which are free of patent and hence cheaper and affordable.

The TRIPS Agreement ${ }^{7}$ allows Member States to impose a more extensive protection

2 See C Fink, 'Intellectual Property and the WTO,' (World Bank, November 2004) $<$ http://www.siteresources.worldbank.org/INTRANETTRADE/Resources/Internal-Training/287823-

1116536061368/IPR-WTO_Fink.doc > accessed 20 March 2015. The TRIPS Agreement marked a clear departure from the narrow negotiations on border measures such as tariffs and quotas commonly encountered during the GATT negotiations, toward the establishment of multilateral rules for trade-affecting measures beyond borders, and came into force on 1 January 1995.

3 See generally, SK Sell, Private Power, Public Law: The Globalization of Intellectual Property Rights (Cambridge, 2003).

${ }^{4}$ Under the Paris Convention for Protection of Industrial Property 1883, contracting parties were permitted to exclude patent protection in certain sectors such as pharmaceuticals, and permitted to determine the duration of patent rights, and grant compulsory license for a variety of reasons. Most of these flexibilities are not available under the TRIPS Agreement.

${ }^{5}$ India, seen as the leading manufacturer of generic drugs in the world, introduced process patent into its legislation in the 1970s, which helped in the production of cheaper medicines to its own use and for export to other developing countries and LDCs. Pharmaceutical products became patentable in France and Germancy in 1967, in Italy in 1979 and in Spain in 1992. See J Sundaram, 'India's Trade-Related Aspects of Intellectual Property Rights Compliant Pharmaceutical Patent Laws: What Lessons for India and Other Developing Countries?' Information \& Communications Technology Law Vol. 23 Issue 1 (2014) 1-30.

${ }^{6}$ Generic drugs contain the same active ingredient as the original brand name product (patented) upon which it is based. Generics are identical to the branded product, provided it is well made. Also, good generics are an affordable alternative to the more costlier brand name products. See MNG Dukes, FM Haaijer-Ruskamp, CP de Joncheere, and AH Rieteld (eds.) in Drugs and Money: Prices, Affordability and Cost Containment (WHO, 2003) 103. Note, the World Health Organization (WHO) has avaoided the use of the term 'generic product' as much as possible, and in its place chosen to use the term 'multisource pharmaceutical product.'

${ }^{7}$ The TRIPS Agreement came into force on 1 January 1995, and is one of the covered Agreements of the World Trade Organization (WTO). Importantly, the TRIPS Agreement is a far more stronger Treaty than any earlier 
of IP right if they wish to, and a minimum standard of protection from others who may not be in favour of an extensive protection. TRIPS Agreement fully incorporates substantive rules contained in other international agreements and Conventions ${ }^{8}$ previously administered by the World Intellectual Property Organization (WIPO). ${ }^{9}$ Developing countries and least developed countries (LDCs) had little or no involvement in the development of the above IP Conventions/treaties, as most were negotiated in the colonial era, ${ }^{10}$ decades before the Uruguay Round of Negotiations that took place in the 1980s-1990s. It is worth pointing that a number of sub-Saharan African countries were made signatories to international Conventions even during the colonial period, without the need for them to be parties. ${ }^{11}$ The Agreement creates rights for producers of intellectual property and obligations for the users, and speaks very little about the rights of the end-users of intellectual property, ${ }^{12}$ in our case the rights of the consumers of such pharmaceutical products. The developing countries, led by India, Brazil, and Argentina strongly opposed the proposal, ${ }^{13}$ which was followed by a detailed paper submitted by India in July 1989 at the negotiations putting forward the developing countries'

international Conventions, in that it is allows for Member Sates to raise disputes before the WTO's Dispute Settlement Body (DSB) for non-compliance of the minimum standards laid down under the Agreement. Both the Paris Convention for the Protection of Industrial Property 1883 (under Article 28(1)), and the Berne Conventions for the Protection of Literary and Artistic Works 1883 (under Article 33(1)) refer disputes to the International Court of Justice, unless the countries involved in a dispute agree on some other method of settlement.

${ }^{8}$ The Paris Convention 1883, and The Berne Convention 1883, were designed to enhance the degree of protection that patent rights holders from developed countries enjoyed in overseas jurisdictions. See $\mathrm{C}$ Deere, The Implementation Game: The Global Politics of Intellectual Property Reform in Developing Countries (OUP, 2009) 53. These two treaties were also aimed at replacing the loose network of reciprocal intellectual property arrangements that European colonial powers had in place in some of the bilateral commercial treaties in the 19th century.

${ }^{9}$ T Cottier, 'The Agreement on Trade-Related Aspects of Intellectual Property Rights' in PFJ Macrory, AE Appleton, and MG Plummer (eds) The World Trade Organisation: Legal Economic and Political Analysis Vol. I (Springer, New York, 2005) 1041-1122, 1043. See UNCTAD-ICTSD, 'Resource Book on TRIPS and Development' (2005) 3. Before the entry of TRIPS Agreement, international intellectual property rights were overseen through a patchwork of treaties administered by the World Intellectual Property Organization (WIPO), including the Paris Convention on Industrial Property and the Berne Convention on Literary and Artistic Works. See also J Sundaram, 'Brazil's Implementation of TRIPS Flexibilities: Ambitious Missions, Early Implementation, and the Plans for Reform' Information \& Communications Technology Law Vol. 23 Issue 2 (2014) 81-116.

${ }^{10} \mathrm{C}$ Deere, The Implementation Game: The TRIPS Agreement and the Global Politics of Intellectual Property Reform in Developing Countries (Oxford, 2009) 8.

${ }^{11}$ Through the mechanism of Article 19 of the Berne Convention the former colonial powers of Britain, France, Italy, Belgium and Spain included their colonies in the accession to the Convention. The original Article 19 of the Berne Convention 1886 reads: "[1] Countries acceding to this Convention shall also have the right to accede thereto at any time on behalf of their colonies or foreign possessions. [2] They may for this purpose make either a general declaration of adhesion that includes all their colonies or possessions, or expressly indicate only those which are included, or which are excluded." See Guide to the Berne Convention for the Protection of Literary and Artistic Works (Paris Act, 1971), WIPO Publication No 615 (E), ISBN 92-805-0002-3 (1978) $<$ http://www.wipo.int/edocs/pubdocs/en/copyright/615/wipo_pub_615.pdf $>23$ March 2015.

12 See, e.g., A Kur and HG Ruse-Khan, 'Enough is Enough - The Notion of Binding Ceilings in International Intellectual Property Protection' Max Planck Institute for Intellectual Property, Competition \& Tax Law, Research Paper Series No. 09-01, (2008) < http://ssrn.com/abstract=1326429> accessed 23 March 2015.

$13 \mathrm{~J}$ Watal, Intellectual Property Rights in the WTO and Developing Countries, (Kluwer Law International 2001) 21. See generally P Drahos, 'Developing Countries and International Intellectual Property Standard-Setting' (2002) UK Intellectual Property Rights Commission Study Paper No 8 $<$ https://www.anu.edu.au/fellows/pdrahos/reports/pdfs/UKCommIPRS.pdf > accessed 23 March 2015. The author points out that during the Cold War, the LDCs had the benefit of India and Brazil's leadership of a broad coalition of developing countries, whose importance faded away gradually. The author also observes that the main reason for developing countries not being able to influence outcomes in international IP standard setting process is the continued use of webs of coercion by the US and EU, both of which remain united on the need for strong global standards of intellectual property protection. 
reasons for opposition for inclusion of an international IP rights protection to the GATT agenda. ${ }^{14}$ Although debated, the paper presented by India ${ }^{15}$ did not produce the desired effect, as towards the latter half of 1989 and the beginning of 1990 almost all developing countries changed their position on the inclusion of international IP rights protection to the GATT agenda, ${ }^{16}$ which effectively brought the curtains on any resistance to the introduction of an international IP rights protection regime in the multilateral trading system.

\subsection{The TRIPS Agreement: Flexibilities, The Doha Declaration \& Sub-Saharan Africa}

The TRIPS Agreement, by strengthening patent protection, had a significant impact on access to life-saving medicines in developing countries and LDCs. ${ }^{17}$ This had especially affected the poor countries that had no infrastructure to produce pharmaceuticals and solely relied on imported generics for their health care needs. ${ }^{18}$ The TRIPS Agreement, most importantly, contains flexibilities in its implementation, which are primarily aimed at benefitting the developing countries and LDCs, ${ }^{19}$ and help them in the pursuit of access to affordable medicines. Scholarly articles written on the subject of flexibilities contained in the TRIPS Agreement, points to the WTO's failure to address the problem of the access to medicines in developing countries and LDCs. ${ }^{20}$ Some of the key pharmaceutical patent-related flexibilities identified include provision for grant of compulsory licensing, parallel importation, and provisions relating to patentable subject matter, ${ }^{21}$ the exhaustion of rights ${ }^{22}$ and parallel

${ }^{14}$ UNCTAD-ICTSD, 'Resource Book on TRIPS and Development' (2005) 6.

15 Ibid 7. India had all along argued that any principle or standard relating to IPRs should be carefully tested against the needs of developing countries, and that it would be inappropriate to focus the discussions on the protection of the monopoly rights of the owners of intellectual property, when almost 99 percent of the patents were owned by industrialised nations. It urged that the group focus on restrictive and anti-competitive practices of the owners of intellectual property rights and evolve standards and principles for their elimination to avoid distortion of trade. It also stressed that substantive standards on intellectual property were more in the realm of socio-economic, industrial and technological development, especially in the case of developing countries.

16 The shift came about due the coercive strategies adopted by the United States, and as a result India found itself isolated in the negotiations. RC Bird \& DR Cahoy, 'The Emerging BRIC Economies: Lessons from Intellectual Property Negotiation and Enforcement' 5 NW J Tech \& Intell Prop 1 (2007) 400, 403-04; J Watal (n 14). For a detailed account of the TRIPS negotiations, see DJ Gervais, 'Intellectual Property, Trade \& Development: The State of Play' Fordham Law Review, Vol. 74 (2005) 505-535. See also F Weitsman, 'TRIPS, Access to Medicines and the "North-South" Conflict After Doha: The End or the Beginning?' Asper Rev In'1 Bus \& Trade L Vol. 67 (2006) 67-102, 78. The author opines that from the very beginning, the developing countries (which would also by default include the LDCs) had no real choice in the negotiations but to succumb to the pressure of developed countries.

17 A Lewinberg, 'Access to Medicines Guide: Guide for Policy Makers and Researchers: Understanding the challenge - Making Essential Medicines Available to the World's Poor' (Toronto: Centre for Innovation Law and Policy, 2003) as cited by F Weistman in 'TRIPS, Access to Medicines and North-South Conflict After Doha: The End or The Beginning?’ Asper Rev Int'l Bus \& Trade L. Vol 67 (2006) 67-102, 87.

${ }^{18}$ Ibid.

${ }^{19}$ World Intellectual Property Organization, 'Patent Related Flexibilities in the Multilateral Legal Framework And Their Legislative Implementation at the National and Regional Levels,' Committee on Development and Intellectual Property, Fifth Session, WIPO (25-30 April 2010).

${ }^{20} \mathrm{~J}$ Sundaram, 'Analysis of TRIPS Agreement and the Justification of International IP Rights Protection in the WTO’s Multilateral Trading System, with Particular Reference to Pharmaceutical Patents' ahead-of-print (2015) $1-43$.

${ }^{21}$ SF Musungu and C Oh, 'The Use of Flexibilities in TRIPS by Developing Countries: Can They Promote Access to Medicines?' South Center (2006). The authors study the TRIPS flexibilities from the perspective of access to affordable medicines.

22 The TRIPS Agreement under Articles 6 and 28(6), and the Doha Declaration under Article 5 (d) allow Member States to determine the scope and extent of exhaustion of patent rights (also known as 'first-sale' doctrine). This position is strongly disputed by the US Delegation to the Council of TRIPS, as it holds the view that Article 6 of the TRIPS Agreement neither allows WTO Members to avail themselves of dispute settlement in relation to questions involving parallel imports, nor authorised parallel imports (Delegation of the United States, Council for 
importation, scope of patentability and optional exclusion, exceptions to patent rights and enforcement. ${ }^{23}$ Not all developing countries were aware that the developed countries (the advocates of a wider global IP rights protection) had a strong public health care system and will be unaffected by the pharmaceutical patent regime of the TRIPS Agreement, ${ }^{24}$ and that it will be the developing countries and the LDCs who will be left to face the enormous burden of a higher IP rights protection. As the public health challenges became explicitly linked to the regulation of international trade ${ }^{25}$ conducted through the WTO, it was becoming increasingly clear that the Agreement would severely restrict access to essential medicines for their citizens, and impede any efforts to control diseases including HIV/AIDS, tuberculosis and malaria. There was a lingering fear amongst the developing countries (including the Sub-Saharan nations), that the inclusion of pharmaceutical patents under the extended IP rights protection of the TRIPS Agreement was likely to increase dependency on brand name pharmaceutical products and affect them severely, resulting in essential medicines becoming unaffordable and beyond their reach. ${ }^{26}$

To complicate matters the flexibilities afforded under the Agreement to the developing countries and the LDCs were viewed narrowly by patent holding developed countries, which took the view that the only flexibility afforded under the Agreement was its staggered implementation in certain cases. This was in stark contrast to the view of the developing countries that the Agreement did not limit their sovereign powers when addressing domestic health crises, such as HIV/AIDS. ${ }^{27}$ The impact of the TRIPS Agreement on public health in developing countries and LDCs became a serious issue. It will not be out of context to point out that a lack of clarity and consensus on the TRIPS flexibilities had hampered the efforts to widen access to antiretroviral (ARVs) treatment in developing and least developed countries, ${ }^{28}$ which factor affected the sub-Saharan African nations severely. ${ }^{29}$ The concerns of the

TRIPS Meeting of June 1822, 2001, JOB(01)/97/Add.5, Council for TRIPS, 28 June 2001). See also WIPO (no 44); CM Correa, 'The TRIPS Agreement and Developing Countries' in PJ Macrory and others (eds.), The World Trade Organisation: Legal, Economic and Political Analysis Vol. II (Springer, 2005) 447.

${ }^{23}$ Deere (n 10) 75. The author suggests the development of national policies on utility models, disclosure of origin of genetic material and prior informed consent, and traditional knowledge (folklore and cultural heritage were also mentioned).

${ }^{24}$ Sundaram (n 20).

${ }^{25}$ SJ Hakonsson and LA Richey, 'TRIPS and Public Health. The Doha Declaration and Africa', Development Policy Review Vol. 25, Issue 1 (2007) 71-90.

${ }^{26}$ Sundaram (n 9) 5. Access to essential medicines is recognised as an indispensable part of the right to health and is viewed as a non-delegable obligation on the part of the State, and cannot be violated based on lack of available resources. 'The Selection and Use of Essential Medicines' WHO Technical Report Series 914 (2002) $<$ http://apps.who.int/medicinedocs/pdf/s4875e/s4875e.pdf $>$ accessed 29 April 2015. The developing countries and the LDCs were apprehensive that the TRIPS Agreement if given effect to could severely restrict access to essential medicines within their jurisdictions and also impede any efforts to control diseases, including HIV/AIDS, tuberculosis and malaria.

${ }^{27}$ For the role played by India on behalf of the developing countries during the negotiations, see generally, J Sundaram, 'India's Trade-Related Aspects of Intellectual Property Rights Compliant Pharmaceutical Patent Laws: What Lessons for India and Other Developing Countries?' Information \& Communications Technology Law Vol. 23 Issue 1 (2014) 1-30.

${ }^{28}$ DOHA+10, TRIPS Flexibilities and Access to Antiretroviral Therapy: Lessons from the Past, Opportunities for the Future, UNAIDS, ISBN: 978929173914 (2011) 6.

${ }^{29}$ Sub-Saharan Africa has the highest incidence of HIV/AIDS in the world today. In 2013, 35 million people were living with HIV/AIDS worldwide, of which 24.7 million were from Sub-Saharan Africa. This region also accounts for almost $70 \%$ of global total of new HIV infection. In the same year, 1.1 million people died of AIDS related causes in Sub-Saharan Africa. Most shockingly only 37\% of patients in Sub-Saharan Africa receive antiretroviral treatment (ART). See UNAIDS, 'Factsheet 2014' (UNAIDS 2014 ) $<$ http://www.unaids.org/sites/default/files/documents/20141118_FS_WADreport_en.pdf $>$ (accessed 12 June 2015). See also SJ Haakonsson and LA Richey (n 25). The authors points out that most ARVs are patented, and its high costs in developing countries limits its access to a very few programme, and relatively few people. 
developing countries (including the African countries) only intensified when the US and EU, along with the transnational pharmaceutical corporations commenced an aggressive campaign against countries that proceeded to take advantage of the IP rights policy options contained in the TRIPS Agreement, ${ }^{30}$ with the most notable legal action being launched against the Republic of South Africa, which sought to amend its Medicines Act and grant unbridled powers to the government to issue compulsory licenses and parallel importing contracts to generic producers of HIV/AIDS drugs. ${ }^{31}$ The campaign against the South African government continued, and would only come to an end when the NGO protesters threatened to disrupt the political campaign of the then US Vice President Al Gore. ${ }^{32}$ Nevertheless, the patent holding transnational pharmaceutical industry persisted with its litigation, and would only withdraw after the NGOs had inflicted public relations damage. ${ }^{33}$ The case not only prised open the debate on the precise meaning of the flexibilities contained in the TRIPS Agreement, but also the principles and objectives embodied in Articles 7 and 8 of the Agreement. ${ }^{34}$

With growing pressure from the African Group, the Council for TRIPS ${ }^{35}$ in June 2001 considered in detail the relationship between public health and TRIPS Agreement. ${ }^{36}$ In November 2001, the Doha Declaration on TRIPS and Public Health ${ }^{37}$ (Doha Declaration) was made, to address the concerns of the developing countries, and also to clarify other divergent views held by the developed nations and developing nations on the application and ambit of the TRIPS Agreement. ${ }^{38}$ The Doha Declaration recognised the right of a Member States to

\footnotetext{
${ }^{30}$ FM Abbott, 'The Doha Declaration on the TRIPS Agreement and Public Health: Lighting A Dark Corner at the WTO’ Journal of International Economic Law, Vol. 5 (2002) 469-505, 471.

${ }^{31}$ Ibid. This involved a private litigation by 39 transnational pharmaceutical corporations against Nelson Mandela and the South African Department of Health to delay the 1997 health reform legislation proposed by the South African government, and severe threats of trade and economic sanctions against the government of the Republic of South Africa. See also SS Marcellin, The Political Economy of Pharmaceutical Patents: Us Sectional Interests and the African Group at the WTO (Ashgate, 2013) 134; SK Sell, 'Books, Drugs and Seeds: The Politics of Access,' Prepared for the Transatlantic Consumer Dialogue, "The Politics and Ideology of Intellectual Property", (Brussels, March 20-21, 2006) 1-80.

32 See FM Abbott, 'The TRIPS-Legality of Measures Taken to Address Public Health Crises: Responding to USTR-State-Industry Positions that Undermine the WTO', in DLM Kennedy and JD Southwick (eds.) in Political Economy of International Trade (CAMBRIDGE, 2002) 311-342. The author in the concluding paragraphs observers as follows: "The United States has gone to an extreme, threatening to impose trade sanctions on developing countries that attempt to address one of the worst public health crises ever faced by human civilization.... The TRIPS Agreement is not only about protecting pharmaceutical industry profits. It is also about the health of the global economy, and about the health of individuals.'

${ }^{33}$ Ibid.

${ }^{34}$ See SS Marcellin (n 31). Besides, it also queried the appropriateness of Article 31 in general and 31(f) in particular. See also S Bartlett, 'Compulsory Licenses Pursuant to TRIPS Article 31 In Light of the Doha Declaration on the TRIPS Agreement and Public Health,' Journal of World Intellectual Property Vol. 6 Issue 2 (2003) 283-310.

${ }^{35}$ The legal basis for the establishment of the Council is found in Article IV.5 of the WTO Agreement, which stipulates that the Council 'shall oversee the functioning' of TRIPS Agreement. The Council for TRIPS is also charged with the monitoring of WTO Members' compliance with their obligations under the TRIPS Agreement. See also UNCTAD-ICTSD, Resource Book on TRIPS and Development (Cambridge University Press 2005$) 739$. ${ }^{36}$ In 1996 the World Health Assembly, which was mandated to report on the impact of the work of the WTO with respect to national drug policies and essential drugs, examined the relationship between public health and the TRIPS Agreement. See resolution on the Revised Drug Strategy, Resolution WHA49.14 (25 May 1996).

37 World Trade Organization, Declaration on the TRIPS Agreement and Public Health, WT/MIN(01)/DEC/2, adopted on 20 November $2001<\mathrm{http}$ //www.wto.org/english/thewto_e/minist_e/min01_e/mindecl_trips_e.pdf> accessed 24 March 2015. The Doha Declaration, besides providing interpretative guidance on the policy of flexibilities embodied in the TRIPS Agreement, also helped clarify the scope of the TRIPS Agreement. See UNAIDS (n 28).

${ }^{38}$ JT Gathii, 'The Legal Status of Doha Declaration on TRIPS and Public Health under the Vienna Convention on the Law of Treaties' Harv JL Tech, Vol. 15 (2002) 291-317, 292-293.
} 
grant compulsory licences, determine the grounds for the grant, and also define as to what constituted a national emergency. ${ }^{39}$ The Doha Declaration, and the 2003 Decision on Implementation of Paragraph $6^{40}$ of the TRIPS Agreement while recognising the right of a country to gain access to medicines were intended to allow access to generic medicines for HIV/AIDS, malaria, and tuberculosis. ${ }^{41}$ Paragraph 4 encapsulated the spirit of the Declaration in the following words:

We agree that the TRIPS Agreement does not and should not prevent Members from taking measures to protect public health. Accordingly, while reiterating our commitment to the TRIPS Agreement, we affirm that the Agreement can and should be interpreted and implemented in a manner supportive of WTO Members' right to protect public health and, in particular, to promote access to medicines for all.

To a greater extent, the Declaration also for the first time recognised that IP and trade rules had a negative impact on access to medicines. Paragraph 3 of the Declaration states that '... also recognise the concerns about access to medicines. ${ }^{42}$ Despite a Declaration coming from the highest trading body, and with a UN commitments in the form of Millennium Goals, ${ }^{43}$ much is still desired from the TRIPS Agreement in terms of access to medicines, ${ }^{44}$ as close to a third of the people worldwide lack affordable essential medicines due to exorbitant prices. The developing countries and $\mathrm{LDCs}^{45}$ still face big challenges when trying to implement the TRIPS flexibilities due to increased intellectual property protection introduced under the TRIPS Agreement, ${ }^{46}$ and through TRIPS plus provisions introduced through free trade agreements (FTAs). ${ }^{47}$ The Doha Declaration's impacted the developing countries, as it has influenced their health policies and in particular their pharmaceutical patent legislation. To some extent the Doha Declaration clarified the scope of the TRIPS Agreement, provided interpretative guidance and political space for the use of flexibilities policy embodied in the TRIPS Agreement, ${ }^{48}$ but unfortunately left unresolved the key issue of exporting products manufactured under a compulsory license to countries without domestic production capacity,

${ }^{39}$ The 2001 Doha Declaration, and the 2003 Decision on Implementation of Paragraph 6 of the TRIPS Agreement recognises the right of a country to gain access to medicines. See, Council WTO General, 'Implementation of Paragraph 6 of the Doha Declaration on the TRIPS Agreement and Public Health,' Decision of the General Council [WT/L/540 and Corr.1] (1 September 2003).

${ }^{40}$ World Trade Organization, Implementation of Paragraph 6 of the Doha Declaration on the TRIPS Agreement and Public Health, WT/L/540 and Corr.1 (2003).

${ }^{41}$ SJ Haakonsson and LA Richey (n 25).

${ }^{42}$ M Childs, 'Ten Years of the Declaration: The State of Implementation' Médecins Sans Frontières Presentation at WIPO- South Centre/ KEI side meeting (November 2011).

43 The United Nations Millennium Development Goal (UN MDG), Target 8.E states that in cooperation with pharmaceutical companies, to provide access to affordable essential drugs in developing countries. United Nations, 'Millennium Development Goals and Beyond 2015'<http://www.un.org/millenniumgoals/global.shtml> accessed 23 March 2015.

${ }^{44}$ According to 2008 figures released by the WHO, approximately a third of the people worldwide lack access to medicines. Further, the high prices of essential medicines act as a barrier in the treatment of millions.

${ }^{45}$ In the instant case the countries of Sub-Saharan Africa.

${ }^{46} \mathrm{C}$ Deere, The Implementation Game: The TRIPS Agreement and the Global Politics of Intellectual Property Reform in Developing Countries (Oxford, 2009) 8. See also United Nations, 'The Millennium Development Goals Report 2013'<http://www.un.org/millenniumgoals/pdf/report-2013/mdg-report-2013-english.pdf> accessed 23 March 2015. Interestingly, the report does not list any entries under $8 \mathrm{E}$ of the Goals, which is aimed at providing access to affordable essential drugs in developing countries.

47 The TRIPS-plus provision embedded into FTAs prove a difficult task to access medicines as it effectively outllaws generics and also requires exteneded protection to pharamaceutial patents beyond the period prescribed under the TRIPS Agreement. 
besides not addressing the promise of increased R\&D in exchange for higher levels of IP protection, which was used as a bargaining chip by the developed countries during the Uruguay Round of negotiations on extended IP rights protection. ${ }^{49}$

If the TRIPS Agreement was a well-concerted effort by the developed countries and their transnational pharmaceutical corporations, then, the Doha Declaration was a hard fought bargain by the developing countries and LDCs led by the African nations and well supported by the NGOs. The lack of clarity on the use of compulsory license under the TRIPS Agreement still proves a major stumbling block for the sub-Saharan African nations in accessing affordable medicines, especially when they strongly rely on generic drugs manufactured in countries like India for most of their health care requirement. ${ }^{50}$ It is however to be noted that some developing countries have used the TRIPS flexibilities to produce and purchase generic antiretroviral medications, and there is also evidence of donor countries now permitting the use of their funds to procure generic antiretroviral medications for least developed countries. ${ }^{51}$ Unfortunately, most sub-Saharan African countries do not fall under the category of developing countries that have utilised such flexibilities to their advantage, as do they do not possess the knowledge economy or the necessary infrastructure to manufacture medicines on their own. The UN Commission on Human Rights on IP and Human Rights goes as far as to state that the WTO is "a veritable nightmare" for certain sectors of humanity, ${ }^{52}$ in that the TRIPS Agreement in some ways encourages, or has as a side-effect human rights violations. ${ }^{53}$ The observations in the report are true in that the sub-Saharan African countries continue to suffer from the implementation of the TRIPS Agreement. The fact remains that, the most marginalised global economic actor at the WTO, the African faction ${ }^{54}$ did not have a major role to play during TRIPS negotiations, ${ }^{55}$ but arguably played an important role in the post-TRIPS era in the lead

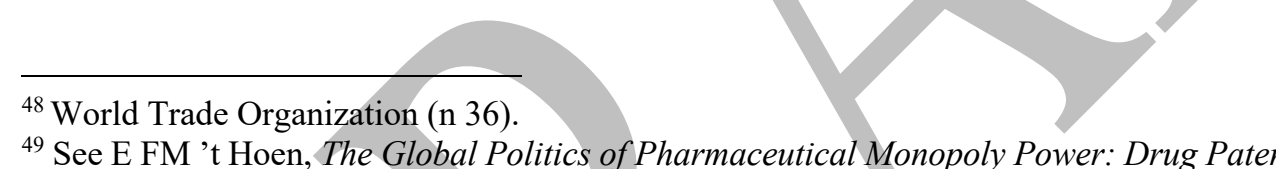

${ }^{49}$ See E FM 't Hoen, The Global Politics of Pharmaceutical Monopoly Power: Drug Patents, Access, Innovation and the Application of the WTO Doha Declaration on TRIPS and Public Health (ABM, The Netherlands, 2009) $2-3$.

${ }^{50}$ As opposed to patented brandname drugs which come at a high price, generic drugs are affordable and cost a fraction of the branded drugs.

${ }^{51}$ The value of donor-funded developing country ARV market has had a dramatic annual growth in recent times. By 2008, Indian generic ARVs accounted for $65 \%$ of the total value (US $\$ 463$ million) of ARV purchases reported. See B Waning, E Diedrichsen \& S Moon, 'A Lifeline to Treatment: The Role of Indian Generic Manufacturers in Supplying Antiretroviral Medicines to Developing Countries' (2010) Journal of International AIDS Society $<\mathrm{http}: / /$ www.biomedcentral.com/content/pdf/1758-2652-13-35.pdf $>$ accessed 24 March 2015.

${ }^{52}$ UN Commission on Human Rights, Sub-Commission on the Promotion and Protection of Human Rights, 'Intellectual Property Rights and Human Rights', Resolution 2000/7, 17 August 2000, para 1 [Document E/CN. 4/Sub.2/2000/2000/7]. The report concludes thus: 'Since the implementation of the TRIPS Agreement does not adequately reflect the fundamental nature and indivisibility of all human rights, including the right of everyone to enjoy the benefits of scientific progress and its applications, the right to health, the right to food and the right to self-determination, there are apparent conflicts between the intellectual property rights embodied in the TRIPS Agreement, on the one hand, and international human rights law on the other.'

${ }^{53}$ F Papadopoulou, 'TRIPS and Human Rights', in A Kur (eds.) Intellectual Property Rights in a Fair Trade System: Proposals for Reform of TRIPS (Edward Elgar 2011) 262.

${ }^{54}$ SS Marcellin (n 31) 135. The author points out that the African Group had been the most marginalized at the WTO until December 2005 WTO decision to amend the TRIPS Agreement.

${ }_{55}$ Marcellin (n 31) 80. The author observes that from the texts and proceedings of the TRIPS negotiations, one could gather that there was no clear engagement (submission/proposal), or a clear standpoint during the negotiations, from the African countries (with the exception of Nigeria and Tanzania's submission in 1990). This factor is especially shocking when one takes into consideration the fact that Africa is the most affected continent from HIV/AIDS, and also the most to lose in an ill-conceived IP protection package affecting pharmaceutical patents. 
up to the Doha Declaration. ${ }^{56}$ The African Groups raised the issue of patents and healthcare as part of the Doha Development Round, ${ }^{57}$ in such a way that it could not be ignored.

\subsection{Problems Facing Sub-Saharan Africa: Extended IP Rights Protection, the Promised Flexibilities and the 'Unachievable Balance' under TRIPS}

Improving access to affordable medicines in the disadvantaged parts of the world had been on the agenda of international bodies for well over four decades, and resulting in the adoption of numerous resolutions and declarations. In the 1980s, when the HIV/AIDS epidemic affected the populations across the globe, the most vulnerable populations were located in the developing and least developed parts of the world - needless to say the concentration continues to be very high in sub-Saharan Africa. While progress has been made in the treatment of the disease, it still remains inaccessible to a majority of the population who suffer from it. Those affected by HIV/AIDS but with access to the best treatment options still live in developed countries, and those with little or no access to medicines and treatment live in developing countries and LDCs, with the majority concentrated in sub-Saharan Africa. ${ }^{58}$ The developed countries hold the patent rights to most medicines, which offer the best treatment options possible for to treat HIV/AIDS. Medicines broadly fall under three categories namely, nonprescription drugs, generic prescription drugs, and patented prescription drugs. Transnational pharmaceutical corporations from patent holding developed countries dominate the market for patented prescription drugs, which are also responsible for the development of new therapies. ${ }^{59}$

Generic medication, which makes up for half the pharmaceutical market, developed in industrialized nations and released into the public domain in the $1970 \mathrm{~s},{ }^{60}$ is the most sought after medicine in sub-Saharan Africa, as it is affordable and hence accessible. As mentioned earlier, most sub-Saharan African countries lack the necessary knowledge economy and research capabilities to identify and treat diseases that affect their countries, besides the necessary infrastructure to produce any medicines. ${ }^{61}$ This is also compounded by the fact that most sub-Saharan African nations also do not posses the necessary administrative and resource capacities to negotiate before international forums, ${ }^{62}$ which is a huge disadvantage, especially in a globalized economy where decisions, touching upon all aspects of human life, are taken on a daily basis.

Due to reduced production costs (especially labour) prevalent in developing countries and LDCs, one may think that it would be possible to produce medication at a cheaper cost in African countries. However, this may not be the case in sub-Saharan Africa, where most countries are without industrial or environmental expertise, and only have limited internal

\footnotetext{
${ }^{56}$ See P Drahos, 'Developing Countries and International Intellectual Property Standard-Setting' The Journal of World Intellectual Property Vol. 5, Issue 5 (2002) 765-89; P Drahos 'Four Lessons for Developing Countries From the Trade Negotiations Over Access to Medicines' Liverpool Law Review, Vol. 28, Issue 1 (2007) 11-39. See also Marcellin (n 31) 135.

57 The Doha Development Round purported to place the needs and interests of developing countries and LDCs at the heart of its work programme. See Marcellin (n 31) 136. The Doha Ministerial Declaration (WT/MIN(01)/DEC/1) (20 November 2001).

${ }^{58}$ Sundaram (n 20) 31.

59 AN Elbeshbishi, 'TRIPS and Public Health: What Should African Countries Do?' (African Trade Policy Centre, January 2007) 1.

${ }^{60}$ Ibid. Interestingly, in developed countries like the US, there are strong incentives to replace patented medications with generic medicines as soon as their patents expire.

${ }^{61}$ Ibid. The author points out that the pharmaceutical industry in some of African countries has evolved, which was motivated by the industrial politics of the 1950s. African countries such as Egypt, Morocco, Kenya and South Africa began to create national pharmaceutical industries to replace imports and essentially produce medications locally, replacing foreign imports. And although Morocco has opened the doors to transnational pharmaceutical corporations, others like Egypt has preferred to support locally financed enterprises. ${ }^{62}$ Ibid.
} 
markets and cannot therefore benefit from the economies of scale as enjoyed by larger countries and multinational companies. ${ }^{63}$ The history of the long drawn negotiations on an expanded IP rights enforcement regime and the entry of the TRIPS Agreement clearly demonstrate that the drafters' intent, although from different ends of the spectrum, was to balance IP rights with access to affordable medicines, ${ }^{64}$ with the goal to provide access to essential medications in cases of national public health emergency by granting a compulsory license of a patented medication. ${ }^{65}$ While the extent of the IP rights protection has been clearly defined in the Agreement, the scope of compulsory licenses has not been defined properly, ${ }^{66}$ which does not help in balancing the countervailing goals of IP rights with access to medicines. ${ }^{67}$ Under the scheme rights holders are seen as producers of goods, while individuals seeking a fairer access to affordable medicines are viewed as mere consumers, with both parties having deeply entrenched goals with differing primary priorities and interests. ${ }^{68}$ One of the major stumbling blocks in achieving the goal of access to medicines appear to be the need to balance the transnational pharmaceutical corporations' profit-seeking behaviour with socially responsible business practice that will permit greater access to essential medicines, ${ }^{69}$ which clearly appears to favour the patent-holding pharmaceutical corporations, as there are no international mechanism, or national mechanisms in developing countries and LDCs to monitor their business practice. Also, most developing countries and LDCs in sub-Saharan Africa, lack the necessary infrastructure to manufacture patentable drugs ${ }^{70}$ and would prefer a weaker IP rights regime $^{71}$ to permit the market entry of affordable generic drugs to its citizens.

\subsection{TRIPS Agreement - A Bane for Sub-Saharan Africa:}

The TRIPS Agreement effectively curtails a Member State's options, and also severely restricts the development policies of State players in ways that were not experienced by developed countries during their own transformations into industrialized countries. ${ }^{72}$ One of the most affected from the Agreement is the sub-Saharan African Member States, as a number of them do not have sufficient infrastructure to compete with developed countries in production of pharmaceuticals and are constrained to rely on imported medicines produced by transnational pharmaceutical corporations. The sub-Saharan African countries that clearly fall under this category have come to increasingly rely on imported and affordable generic drugs from outside the continent. It is necessary to point out that the trade-off as promised by the developed countries during the Uruguay Round of Negotiations did not happen, ${ }^{73}$ although it

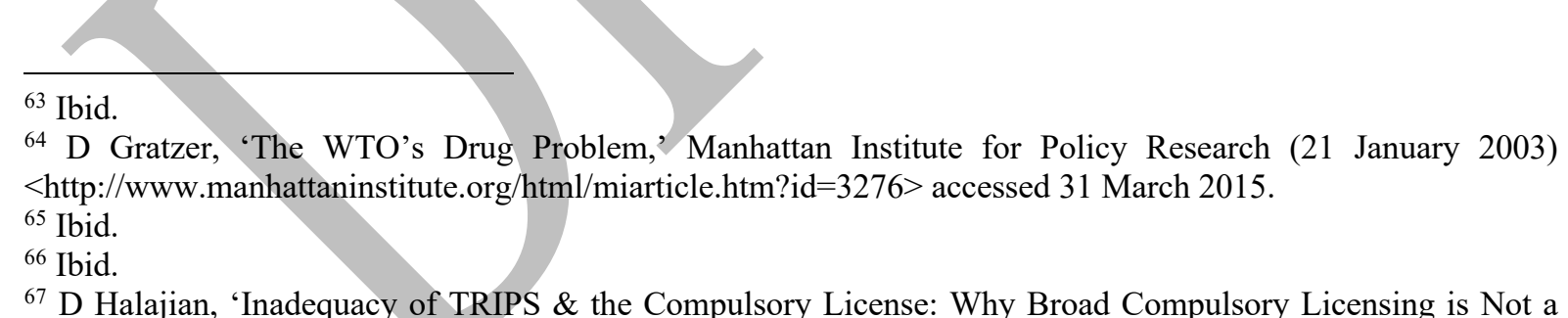

D Halajian, 'Inadequacy of TRIPS \& the Compulsory License: Why Broad Compulsory Licensing is Not a The author also argues that TRIPS has not been utilized to its fullest.

68 AG Watson, 'International IP Rights: Do TRIPS' Flexibilities Permit Sufficient Access to Affordable HIV/AIDS Medicines in Developing Countries?,' B.C. Int'l \& Com. 1. Rev, Vol. 32 (2009) 143-159, 149-150.

69 B Whobrey, 'International Patent Law and Public Health: Analyzing TRIPS' Effect on Access to Pharmaceuticals in Developing Countries,' Brandeis L. J., Vol. 45 (2007) 623-642, 623-624.

${ }^{70}$ DCK Chow and E Lee, International Intellectual Property: Problems, Cases, and Materials (Thomson West, 2006) 12.

${ }^{71}$ Whobery (n 43) 625.

72 S Joseph, Blame It On the WTO? A Human Right Critique (Oxford 2013) 267.

${ }^{73}$ RC Dreyfuss, 'The Role of India, China, Brazil and Other Emerging Economies in Establishing Access Norms for Intellectual Property and Intellectual Property Law Making' IILJ Working Paper 2009/5, NYU School of Law, (2009) $4<$ http://ssrn.com//aol3/papers.cfm?abstract=11442785> accessed 28 January 2014. According to the 
is two decades since the introduction of the TRIPS Agreement into the multilateral trading system. To a great extent the gap in the knowledge economy between the developed and the developing countries (North-South divide) contributed to their ignorance of the TRIPS Agreement's implication and the flexibilities offered therein, ${ }^{74}$ needless to say that the African nations barely engaged in the TRIPS negotiations, ${ }^{75}$ which was to prove very costly. SubSaharan Africa, predominantly formed by developing countries and LDCs, is a classic case where knowledge economy is very nearly barren in the continent with the exception of a few countries, due to a number of reasons including poverty, illiteracy, long period of military dictatorship with no recourse to development, very poor governance, corruption, etc. Again, some of the diseases which are viewed as manageable and not so life threatening in the developed countries are still life threatening and not manageable in most parts of sub-Saharan Africa - the classic cases being AIDS/HIV, malaria, diabetes, etc. In sum it is the WTO, lead by the developed countries, which is solely responsible for creating a multilateral trading system that promotes private ownership of knowledge through the TRIPS Agreement. ${ }^{76}$

The current structures and incentives of the pharmaceutical industry, which is largely based on IP laws, do not incentivize research into medicines for neglected diseases that afflict citizens living in sub-Saharan African countries, but not to be found in developed countries. ${ }^{77}$ To address the inequality in research created by pharmaceutical corporations, some authors have suggested alternative schemes for incentivizing pharmaceutical research, ${ }^{78}$ to make it more easily accessible in developing countries and LDCs. Here again, the Ebola ${ }^{79}$ outbreak, which was witnessed in parts of West Africa in 2014, presents us with a snap shot of the urgency with which transnational pharmaceutical corporations carry out research for potential cure, or treatment for diseases. Although the Ebola virus was first discovered in 1976, no breakthrough had yet been made in 2014 when parts of West Africa witnessed a major outbreak of the virus, which claimed close to 5000 lives. ${ }^{80}$ The most severely affected countries of the

author's analysis the trade-off was access to foreign markets in exchange for raising domestic intellectual property levels, which was a losing proposition.

${ }^{74}$ Ibid.

${ }^{75}$ Marcellin (n 54).

${ }^{76}$ Joseph (n 70). The author opines that the TRIPS Agreement vests IP rights holders with very broad and generous rights at the expense of human rights, and goes on to recommend a rollback of the TRIPS Agreement through the grant of greater flexibility in the implementation for developing countries.

77 Joseph (n 70) 239. The author also notes that pharmaceutical patents incentivize research directed at 'symptom relief' rather than finding permanent cures.

${ }^{78}$ See generally, T Pogge, 'The Health Impact Fund: Better Pharmaceutical Innovations at Much Lower Prices' in T Pogge, M Rimmer, and K Rubenstein (eds) in Incentives for Global Public Health (Cambridge, 2010) 135154. The author proposes an alternative scheme where the countries contribute to a 'Health Impact Fund' from where pharmaceutical innovators are paid depending on the impact of their products on health. This, in the view of the author would not only incentivize products which cure diseases, but would also encourage lower prices increasing the health impact of a product.

79 The World Health Organisation (WHO) describes Ebola virus disease (EVD) as 'a severe, often fatal illness in humans.' The disease is mainly found in tropical Central and West Africa, and can have a 90 per cent mortality rate. The first outbreak of Ebola was experienced in 1976 in two simultaneous locations, namely, Nzara, Sudan, and Yambuku, Democratic Republic of Congo. The village of Yambuku is situated near the Ebola River, from which the disease takes its name. See P Sawer, 'Ebola Facts: What is it and How is it Transmitted?' The Telegraph (29 December 2014) <http://www.telegraph.co.uk/news/worldnews/ebola/11171600/Ebola-facts-What-is-Ebolaand-how-is-it-transmitted.html $>$ accessed 9 May 2015; WHO - Media Centre, 'Ebola Virus Disease - Fact Sheet No 103' (WHO, April 2015) < http://www.who.int/mediacentre/factsheets/fs103/en/> accessed 9 May 2015.

${ }^{80}$ The figure of 5000 in WHO's view, is speculative and could be three times more, bringing the death toll close to 15,000. T Miles 'Official WHO Ebola Toll Near 5,000 with True Number Nearer 15,000' (Reuters 22 October 2014 ) <http://www.reuters.com/article/2014/10/22/us-health-ebola-who-idUSKCN0IB23220141022> accessed 9 May 2015. The figures available as of 6 May 2015 put the death toll from 2014 outbreak of Ebola virus at 11,007. 
Ebola outbreak in 2014, namely Guinea, Liberia and Sierra Leone, have very weak health care systems, and lack human and infrastructural resources. ${ }^{81}$ To make matters worse they have only in recent times emerged from long periods of conflict in the region and experience instability. ${ }^{82}$ To have high expectations of IP rights/law compliance in the above jurisdictions, as laid out under the TRIPS Agreement, is simply unacceptable and shocking, and makes one ask the question if the WTO had considered all of the arguments before giving the go-ahead for the implementation of the Agreement? The answer is easy to arrive at, as the negotiation history of the TRIPS would demonstrate that there was no level playing field in the late 1980's and 1990s when the extended IP protection under the multilateral trade agenda was debated. This brings us back to the point made earlier, i.e., the disengagement, or lack of any clear presence of African Group in the TRIPS negotiation process, their lack of understanding of the gravity of the process that would introduce a system of IP protection on them through the WTO, which would have a damning effect on their health care. ${ }^{83}$ It was pointed out earlier ${ }^{84}$ that sub-Saharan African countries are weak on knowledge economy and also lack the capacity to participate/represent in international forums, a factor which would make them a very vulnerable player in a high level negotiation debating the introduction of IP rights protection globally through the soon-to-be-born WTO.

To postpone compliance to the TRIPS Agreement cannot be a solution to the problems facing sub-Saharan Africa. ${ }^{85}$ Currently, the LDC Member Countries are not required to apply most of the substantial rules of the TRIPS Agreement until 1 July 2021, and in particular, they have no obligation to provide any protection for clinical test data or to grant patents, including on pharmaceutical products or processes. ${ }^{86}$ As recently as February 2015, LDCs led by Bangladesh, have presented a proposal to the TRIPS Council to have their deadline extended for protecting and enforcing pharmaceutical patents and clinical data as long as the Member State remains an LDC. ${ }^{87}$ Some of the reasons stated for the extension included the lack of technological base and local pharmaceutical manufacturing capacity in the LDCs. ${ }^{88}$ It can also be added that this proposal received support from a number of developing countries, developed countries (including the Holy See, Chile and Norway) and the WHO in the meetings held in June 2015, and will be taken up for further discussion when the council meets on 15-16 October

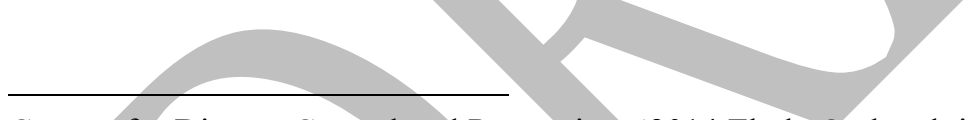

Centers for Disease Control and Prevention, ‘2014 Ebola Outbreak in West Africa - Case Counts' (CDC 9 May 2015).

${ }^{81}$ WHO (n 53).

${ }^{82}$ WHO (n 53).

${ }^{83}$ Marcellin (n 54); Stiglitz (n 1).

${ }^{84}$ Elbeshbishi (n 60).

85 The LDCs, under Article 65.1 of the TRIPS Agreement, were granted a 10-year of a transition period for the implementation of the Agreement, which included product patent protection of pharmaceutical inventions. In 2001 pursuant to Paragraph 7 of the Doha Declaration on the TRIPS Agreement and Public Health instructed the transition period relating to pharmaceutical products was extended up to 1 January 2016. It is to be noted that this extension was done without prejudice to the possibility of further extension of the transition period.

${ }^{86}$ Infojustice, 'World Health Organization Statement on Proposed Extension of TRIPS Transition Period For Least Developed Countries' (15 June 2015) <http://infojustice.org/archives/34572> accessed 18 June 2015.

${ }^{87}$ WTO, 'Poorest States Seek More Time On Medical Patents, and Members Discuss Women and Innovation' (WTO 24 February 2015) <https://www.wto.org/english/news_e/news15_e/trip_24feb15_e.htm> accessed 18 June 2015.

${ }^{88}$ The proposal states that as of 2011, some 9.7 million of the 34 million people affected by AIDS/HIV live in LDCs, and that 4.6 million of the HIV/AIDS sufferers living in LDCs were eligible for ARV treatment in accordance with the 2010 WHO HIV Treatement guidelines, but only 2.5 millioin were receiving it. The proposal also highlights the complex challenges facing LDCs with respect to second line AIDS/HIV treatment which is more than twice the price of the first line regime, and third line AIDS/HIV treatment could be 15 times the price of first line treatment. 
$2015 .{ }^{89}$ There are currently 48 LDCs in the United Nation's list, of which 34 are WTO Member States, and most importantly they are predominantly located in the sub-Saharan Africa and Asia. ${ }^{90}$

In the view of leading economists, the patent system is identified as giving rise to high cost of medicines, which in turn impedes access to lifesaving drugs for billions. ${ }^{91}$ One of the main reasons the transnational pharmaceutical industry was strongly advocating for an extended IP rights protection regime through TRIPS was that they wanted to reduce access to generic medicines, as the prices of generic drugs are very low and are favoured over the much higher priced patented drugs. ${ }^{92}$ And also, any competition with the generics drugs will drive down the price of the brand name drugs. Also, the lower prices in turn lowers the profits of the brand name pharmaceutical companies, and that it is understandable why the transnational pharmaceutical corporations pushed so hard and also contributed for international IP rights protection. ${ }^{93}$ The developed nations who advocated for a wider, global IP protection are clearly not affected by the rising cost of access to affordable medicines, as they have in place a robust health care system through which medicines are accessible to its citizens. ${ }^{94}$ Importantly, antiretroviral drugs (ARVs), in developed countries, have "transformed AIDS from a death sentence to a chronic illness and saved thousands of lives," but in sharp contrast, in sub-Saharan Africa, even at the reduced price of $\$ 300$ per year the drugs remain out of reach for millions suffering from HIV and AIDS. ${ }^{95}$ Sub-Saharan Africa is the region most affected by the HIV/AIDS epidemic, and although it boasts only 10 percent of the world's population, it nonetheless accounts for 66 percent of all HIV cases and more than 75 percent of AIDS-related deaths worldwide. ${ }^{96}$ It is well known that ARVs are the only proven means of staving off AIDS, and that so many in sub-Saharan Africa do not have access to ARVs is problematic - both morally and medically. ${ }^{97}$ Unfortunately, for the AIDS patients living in sub-Saharan Africa,

\footnotetext{
${ }^{89}$ In June 2015, the proposal was taken up for further hearing and received the much needed support from a number of developing and developed countries and will be taken up for a full discussion in October 2015. The WHO issued a statement expressing its full support for the proposal. See Thiru Balasubramaniam, 'WTO TRIPS Council: World health Organization Issues Unequivocal Support to LDC Transition Period for Pharmaceutical Products' (Knowledge Ecology International, 10 June 2015) <http://keionline.org/node/2244> accessed 18 June 2015.

90 World Trade Organization, 'Understanding the WTO: Least Developed Countries' (WTO 2015) $<$ https://www.wto.org/english/thewto_e/whatis_e/tif_e/org7_e.htm> accessed 15 June 2015. With the exception of Timur-Leste, Solomon Islands, and Vanuatu, the rest of the LDCs are located in 2 continents.

${ }^{91}$ J Stiglitz, 'Economic Foundations of Intellectual Property Rights' Duke Law Journal Vol. 57 (2008) 1693-1724, 1701.

${ }^{92}$ Ibid.

${ }^{93}$ Ibid.

94 Sundaram (n 20).

95 'Paying the Price' (Television Trust for the Environment, U.S. Release 2002) $<\mathrm{http}$ ://tve.org/films/paying-theprice/index.html $>$ accessed 20 June 2015; McClellan (n 190) 154. See also DT Jamison, JG Breman, AR Measham, G Alleyne, M Claeson, DB Evans, P Jha, A Mills, P Musgrove, 'Cost-Effective Strategies for the Excess Burden of Disease in Developing Countries,' in Priorities in Health (World Bank, 2006) 59-95. $<$ https://openknowledge.worldbank.org/bitstream/handle/10986/7045/364600Prioriti101OFFICIAL0USE0ONL Y1.pdf?sequence $=>$ accessed 19 June 2015. The authors argue that many of the diseases and health conditions that account for a large part of the disease burden in low- and middle-income countries are far less common in high-income countries. Also, according to the authors, just eight diseases and conditions account for 29 percent of all deaths in low- and middle-income countries, namely, TB, HIV/AIDS, diarrheal diseases, vaccinepreventable diseases of childhood, malaria, respiratory infections, maternal conditions, and neonatal deaths.

96 Jamison et al (91) 61.

${ }^{97}$ A Fint, HIV/AIDS in Sub-Saharan Africa: Politics, Aid and Globalization (Palgrave Macmillan, 2011) 185. The author portrays the transnational pharmaceutical corporations as the 'ready made villains' in the HIV/AIDS story, for making billions of dollars in profits whilst people across sub-Saharan Africa died. The author further points out that the African HIV/AIDS crisis has revealed itself as a 'complexity of interrelated actors, institutions and practices lacking both clearly identifiable 'villains' and simple solutions.'
} 
the ARVs for frontline treatment are inaccessible due to its exorbitant price, which is fixed by transnational pharmaceutical corporations. ${ }^{98}$ Patients from sub-Saharan Africa suffer most from the impact of TRIPS, as the implementation of the Agreement has seen the price of patented drugs rise exponentially in a very short time, defying any logic. ${ }^{99}$ The only option available for countries in sub-Saharan Africa is the use of generics, the procurement of which has now become highly problematic due to restriction placed on parallel imports and compulsory licensing under the Agreement. It will not be an exaggeration to state that the production and procurement of generics has almost been outlawed by the implementation of the TRIPS Agreement. One should bear in mind that the rules regulating the governance of multilateral trade are key to the future of HIV/AIDS treatment across the globe, particularly in poorer regions, sub-Saharan Africa being one, where price concerns can mean the difference between life and death. ${ }^{100}$ The extensive sufferings witnessed in sub-Saharan Africa due to HIV/AIDS over the decades have prompted some to refer to the region as 'ground zero' of HIV/AIDS. ${ }^{101}$ Some writers even refer In essence, the TRIPS Agreement has struck a discord, and only made access to life saving medicines an even more difficult task to achieve in subSaharan Africa and other disadvantaged parts of the world.

\section{The Existence of Medicines does not Guarantee Treatment}

Some writers have identified poverty as one of the main reasons for not being able to access medicines, and even those governments that are not corrupt or otherwise woefully dysfunctional, lack the resources and infrastructure to get them to those who need medicines but cannot afford them. ${ }^{102}$ This particular factor is used by the pharmaceutical industry to stave off any argument that patent rights allow them to set high prices that keep life-saving drugs out of the reach of the poor. ${ }^{103}$ In the 21 st Century globalised economy, the existence of medicines,

\footnotetext{
${ }^{98}$ Ibid. The author opines that the role of transnational pharmaceutical companies in HIV/AIDS management is controversial, which is due to the increased protection afforded to the IP rights of their products. See also UNAIDS, Joint UN Programme on HIV/AIDS Staff, 2006 Report on the Global AIDS Epidemic (World Health Organization 2006) 13-14. The Report states that millions have died of this terrible disease - 2.6 million in 2003 and 2.8 million in 2005, of which sub-Saharan Africa contributed 1.9 million and 2.0 million respectively.

99 Sundaram (n 20).

${ }^{100}$ Fint ( $\mathrm{n}$ 97). The author also points out that the extension of IP rights protection to pharmaceutical patents across the globe has cemented the transnational pharmaceutical corporations' control over the international pharmaceutical market and, with it, their ability to control prices and access. See also HA Waxman, 'Pharmaceutical Industry Profits Increase by over \$8 Billion after Medicare Drug Plan goes into Effect', Committee on Government Reform, US House of Representatives, (September, 2006). The author points out that in 2006, the American-based pharmaceutical conglomerates of Pfizer, Johnson \& Johnson, Merck \& Co, Eli Lilly \& Company, Proctor \& Gamble, and Bristol-Meyers, collectively and other top ten economic pharmaceutical performers produced profits of nearly $\$ 40$ billion in an international market worth close $\$ 640$ billion.

${ }^{101}$ Fint (n 97) 169.

102 G Dutfield, 'Delivering Drugs to the Poor: Will the TRIPS Amendment Help' Am JL \& Med, Vol. 34 (2008) 107-124. See L Ferreira, 'Access to HIV/AID Drugs: The Human Rights Obligations of Multinational Pharmaceutical Corporations' Fordham L Rev Vol. 71 Issue 3 (2002) 1133-1180, pp.1133-1135. The author argues that poverty is a potent cause of death in developing countries with significant poor population, and that a vast proportion of patients in developing countries may die because the medicines to control the progression of diseases are unaffordable. See also EFM 't Hoen, 'TRIPS, Pharmaceutical Patents and Access to Essential Medicines: Seattle, Doha and Beyond' in Economics of AIDS and Access to HIV/AIDS Care in Developing Countries: Issues and Challenges (Agence Nationale de Recherches sur le SIDA (ANRS), 2003) 39-67. The author argues that the important reason for the lack of access to medicines in many cases is the high prices of drugs, which acts as a barrier to much needed treatments, and that prohibitive drug prices are often the result of strong IP Protection.

${ }^{103}$ Ibid. See also T Jones, Commentary, in Public Health, Innovation and Intellectual Property Rights: Report of the Commission on Intellectual Property Rights, Innovation and Public Health (World Health Organization, 2006) 202, where it is observed that "Concerning access, patents are not the issue but the overwhelming poverty of individuals, absence of state healthcare financing, lack of medical personnel, transport and distribution
} 
or cure, does not guarantee their accessibility to the poor and needy in developing countries and LDCs, who were compelled to embrace an intellectual property regime under the TRIPS Agreement, which is to their absolute disadvantage. ${ }^{104}$ The idea of withholding (or denying access to) life-saving drugs from individuals suffering from fatal or debilitating diseases when the means exist to distribute those drugs cheaply and effectively is anathema to all notions of morality. ${ }^{105}$ Under international human rights laws, the right to health includes elements related to healthcare - which includes access to medicines, curative and preventive health care, and other aspects related to a number of 'underlying preconditions for health.' ${ }^{106}$ The Committee on Economic, Social and Cultural Rights (CESCR) interpreted the understanding of the 'highest attainable standard of health' as "a right to the enjoyment of a variety of facilities, good, services and conditions necessary for the realisation of the highest attainable standard of health," 107 and access to necessary medicines should be understood in light of this explanation.

Authors haver argued that the TRIPS Agreement cannot be viewed as just, and highlighting the fact that representatives of a number of acceding governments included individuals such as Suharto (Indonesia), Mugabe (Zimbabwe), Sani Abacha (Nigeria), Mobutu Sese Seko (Democratic Republic of Congo), and Burma's SLORC junta, who could not have represented the best interests of the people they were ruling. ${ }^{108}$ By globalizing the pharmaceutical patent regime the developed countries have imposed a very costly loss of freedom on the global poor coming from developing countries and LDCs, thereby cutting off poor patients from their generic drug supply and exposing billions of vulnerable people to heightened risk of death and disease. ${ }^{109}$ It can be argued that pharmaceutical patent holding developed countries have used the TRIPS Agreement to effectively set a bench-mark on IP rights standards and have exploited the loop-holes in the multilateral trading system, which allows for regional trade agreements (RTAs), to effectively prevent the developing countries from implementing the TRIPS flexibilities. ${ }^{10}$

\subsection{The Proposal for An Amendment}

In the preceding paragraphs we identified some of the disadvantages that blight the subSaharan African countries from accessing affordable medicines. One of the disadvantages identified is the lack of manufacturing capacity and, or the economic viability to either produce active ingredients, or formulations. This particular factor disadvantages the sub-Saharan African countries to the most as it deprives them from availing the provisions of 'compulsory

infrastructure plus supply chain charges which can make affordable originator or generic products unaffordable. In many countries, medicines are unaffordable from whatever source, price or patent status."

104 Sundaram (n 20).

105 T Pogge, 'Access to Medicines' (2008) 1(2) Pub Health Ethics 73-82, 74. The author refers to TRIPS as a 'notorious' Agreement, which had globalised a monopoly patent regime, which keeps the prices of advanced medicines much higher than the long-run cost of production by suppressing generic competition. He also argues that this excludes the global poor from access to vital medicines for the sake of enhancing the incentives to develop new medicines for the affluent.

106 Ibid, 75. The author argues that the current international rules, which are shaped by developed/wealthier countries, contribute to massive deprivations among the disadvantaged, and are therefore unjust, and those responsible for the design and imposition of the said rules are not merely failing to protect human rights, but are actively violating the rights of billions.

${ }^{106}$ B Toebes, 'Towards an Improved Understanding of the International Human Right to Health,' Human Rights Quarterly Vol. 21 No 3 (1999) 661-679, 665-71;

${ }^{107}$ See Council on Economic, Social and Cultural Rights (CESR), General Comment No 14, 22nd Sess, (4 July 2000) para 9 [Document E/C.12/2000/4].

108 Pogge (n 105) 76.

${ }^{109}$ T Pogge, 'Medicines for the World: Boosting Innovation Without Obstructing Free Access,' SUR - Int'l J on Hum Rts Vol. 8 (2008) 117-140.

110 Sundaram (n 20). 
licenses' under the TRIPS Agreement. Also, the option of importing generic medicines from other countries is restricted in the Agreement, as it requires production under compulsory licence to be predominantly for the supply of the domestic market. ${ }^{111}$ It would be pertinent here to discuss the implementation of paragraph 6 of the Doha Declaration and the proposed amendments to the Agreement made in 2005. Paragraph 6 of the Doha Declaration reads as follows:

WTO members with insufficient or no manufacturing capacities in the pharmaceutical sector could face difficulties in making effective use of compulsory licensing under the TRIPS Agreement.

Recognizing the above problem, the Council for TRIPS was directed to find an expeditious solution, and to report back to the General Council before the end of 2002. After nearly two years of negotiations, on 30 August 2003, ${ }^{112}$ the General Council of the WTO finally adopted the Decision on Implementation of paragraph 6 of the Doha Declaration on the TRIPS Agreement and Public Health (the August Decision). The paragraph 6 solution was essentially an interim waiver with regard to the obligations under 31 (f) and $(\mathrm{h})^{113}$ of the TRIPS Agreement, which allows for the total quantity of drugs produced under a compulsory licence to be exported. This waiver envisaged under paragraph 6 shall terminate on the date on which an amendment to the TRIPS Agreement replacing its provisions takes effect for a member. ${ }^{114}$ Any implementation of the Decision will require carrying out changes to national laws, and also ensuring that countries do not assume TRIPS-plus obligations under bilateral or regional trade agreements (RTAs). ${ }^{115}$ Since August 2003, the Council for TRIPS had met annually to review the implementation of Paragraph 6 of the Doha Declaration, and as per paragraph 8 , 'with a view to ensuring its effective operation, and shall annually report on its operation to the General Council.' ${ }^{116}$ On 6 December 2005 the WTO Member States reached an agreement on

${ }^{111}$ Sundaram (n 20).

${ }^{112}$ Implementation of Paragraph 6 of the Doha Declaration on the TRIPS Agreement and Public Health WT/L/540 (30 August 2003) <http://www.wto.org/english/tratop_e/trips_e/implem_para6_e.htm> accessed 20 June 2015.

113 Article 31 - Other Use Without Authorization of the Right Holder: Where the law of a Member allows for other use of the subject matter of a patent without the authorization of the right holder, including use by the government or third parties authorized by the government, the following provisions shall be respected:...(f) any such use shall be authorized predominantly for the supply of the domestic market of the Member authorizing such use;...; (h) the right holder shall be paid adequate remuneration in the circumstances of each case, taking into account the economic value of the authorization.

${ }^{114}$ A waiver in this regard does not imply any change of substantive treaty obligations; it only temporarily suspends their operation (Article 57 of the Vienna Convention on the Law of Treaties). A WTO waiver means that a Member shall not initiate a complaint against another Member if the latter acted under the terms of the adopted waiver. However, to the extent that a Member's national law is not revised to implement the terms of the waiver, patent owners may invoke provisions in the national law to block the export of a patented drug by other companies. D Matthews, 'WTO Decision on Implementation of Paragraph 6 of the DOHA Declaration on the TRIPs Agreement and Public Health: A Solution to the Access to Essential Medicines Problem?' Journal of International Economic Law Vol. 7 No.1 (2004): 73-107. See also CM Correa, 'Implementation of the WTO General Council Decision on Paragraph 6 of the Doha Declaration on the TRIPS Agreement and Public Health,' Essential Drugs and Medicines Policy, $\quad$ (WHO, 2004$) \quad 7$. $<$ http://apps.who.int/iris/bitstream/10665/68743/1/WHO_EDM_PAR_2004.4_(2).pdf?ua=1> accessed 21 June 2015. The author notes that bilateral agreements established by the US with some developing and developed countries (e.g., Australia, the Central American countries, Chile, Jordan, Morocco) require the protection of data under a sui generis regime of data exclusivity for at least five years from the date of the first approval of a pharmaceutical product in the country.

115 Correa (n 114).

116 Sundaram (n 20). 
the amendment to the TRIPS Agreement, ${ }^{117}$ and this proposal, if and when given effect to, will make the temporary waiver of Article 31(f) of the Decision taken on 30 August 2003, a permanent feature. Any decision to review the TRIPS Agreement can only be enforced if the protocol to amend the Agreement is accepted by a two third majority of the Member States, and the WTO will keep the said Protocol open for acceptance by Member States until 31 December 2015. Worryingly, such changes to the TRIPS Agreement will only take effect for those Members States who have signed up for an amendment. For each of the remaining Member States, the waiver will continue to apply until that member accepts the amendment.

\section{Discussion \& Conclusion}

With a mere five months to go, only 58 Member States (as of 29 July 2015) have desired an amendment of the Agreement, ${ }^{118}$ out of which there are only 8 countries from sub-Saharan Africa. This is a worrying development, as a number of the sub-Saharan African countries that are being affected (and who will be affected even more in the coming months and years), have not expressed their wish for an amendment to the Agreement. Given the fact what is sought to be made permanent is the temporary waiver brought under paragraph 6 of the Doha Declaration, which will pave the way for exporting and importing generic drugs under the compulsory licensing provision of the TRIPS Agreement it is a real concern that there is very little engagement in this regard from the developing countries and LDCs. This clearly demonstrates, not an indifference towards the issue, but an ignorance of the magnitude of the problem that the TRIPS Agreement had brought about in the access to medicines in the developing countries and LDCs.

The feeble voice one hears from the sub-Saharan Africa is not for free medicine but a deafening cry for access to affordable medicines. It should be seen as the failure of the WTO to develop an adequate solution to the AIDS issue, which is emblematic of a broader truth about global intellectual property rights and the developing world. ${ }^{119}$ To a greater degree, the WTO, as an agency of the United Nations (UN) and the world governing body that administers the TRIPS Agreement, should be made accountable in its failure in not finding an effective solution to access to medicines in most of its Member States, ${ }^{120}$ and more particularly in sub-Saharan Africa. The argument that Doha declaration was especially formulated to address this issue, and that flexibilities were built into the TRIPS Agreement to address the specific issue cannot be sustained, as they have proven to be ineffective in most cases. Most of the sub-Saharan African countries suffer due to lack of access to medicines, but a mere 8 Member States ${ }^{121}$ from the region have expressed their desire for an amendment. ${ }^{122}$ Sadly, a majority of the countries

\footnotetext{
${ }^{117}$ Amendment of the TRIPS Agreement: Decision of 6 December 2005, World Trade Organization [WT/L/641 8 December 2005]. It is to be noted that the TRIPS Agreement had never been amendment since its entry on 1 January 1995.

118 See INTELLECTUAL PROPERTY: TRIPS AND PUBLIC HEALTH, 'Members Accepting Amendment of the TRIPS Agreement,' WTO (2014) <http://www.wto.org/english/tratop_e/trips_e/amendment_e.htm> accessed 30 July 2015.

119 P Drahos and J Braithwaite, 'Three Tests of US Trade Policy on Intellectual Property Rights', Nth Position (July 2003) <http://www.nthposition.com/threetestsofustrade.php> accessed 31 May 2015.

120 Sundaram (n 20).

${ }^{121}$ The following countries have signed up for an amendment of the TRIPS Agreement: Botswana (18 June 2014), Central African Republic (13 January 2014), Kenya (21 July 2015), Rwanda (12 December 2011), Senegal (18 January 2011), Togo (13 March 2012), Uganda (12 July 2010), and Zambia (10 August 2009). The list is correct as of 29 July 2015. See INTELLECTUAL PROPERTY: TRIPS AND PUBLIC HEALTH, 'Members Accepting Amendment of the TRIPS Agreement,' (n 118).

${ }^{122}$ It should be noted that the African Continent is still in the grip of HIV/AIDS and most number of deaths are still reported in Africa than in any other Continent in the world. The non-availability of affordable ARVs still remains as the main problem in the fight against HIV/AIDS.
} 
in sub-Saharan Africa rely on generic drugs for treatment, and do not possess the necessary infrastructure to manufacture any generic drugs that they need for frontline treatment. Africa as a continent will stand to benefit through a full support of the amendment to the TRIPS Agreement from its WTO Member States. It is yet to be seen if the 31 December 2015 deadline will come to pass, or if the proposed amendment, as in the past, will get another extension.

Some authors while advocating for a review of the TRIPS Agreement, argue that the agenda should include the 'question of its removal from the WTO so that the trade organisation can return to its mission of promoting balanced trade options. ${ }^{123}$ This suggestion presents a strong argument, as it is predicated on the premise that the WTO had deviated from its main objective of balanced trade options, and that the TRIPS Agreement has not worked for the majority of the Member States of the WTO. Viewed from the sub-Saharan African countries interest, it is definitely a way forward, as neither is making the waiver under Article 6 a permanent feature of the TRIPS Agreement going to solve the problem permanently, nor is the proposal to the TRIPS Council to have their deadline extended for protecting and enforcing pharmaceutical patents and clinical data as long as the Member State remains an LDC, going to solve the larger problem created by an extended IP rights protection granted to pharmaceutical patents. One should realise that the WTO had created a beast in the TRIPS Agreement and until and unless its ill effects are neutralised through a complete amendment to exclude protection for pharmaceutical patents from its ambit, the problems facing sub-Saharan Africa and other disadvantaged countries around the world with regards to access to medicines will not go away. The current study had looked at the negotiation process where the African countries made very little contribution, and later in the post-TRIPS era the African countries showed leadership and made a positive contribution in the discussions in the lead up to the Doha Declaration. While the efforts and contributions from the African countries during the Doha Declaration is laudable, their silence, or inaction to sign up and seek an amendment to the TRIPS Agreement to make the temporary waiver under Article 6 of the Doha Declaration into a permanent feature of the TRIPS Agreement is deafening. Time is running out for subSaharan Africa (and other LDCs too), and unless it acts fast, the problem of access to medicines it faces will not go away, and the TRIPS Agreement in its current form could make it a permanent feature.

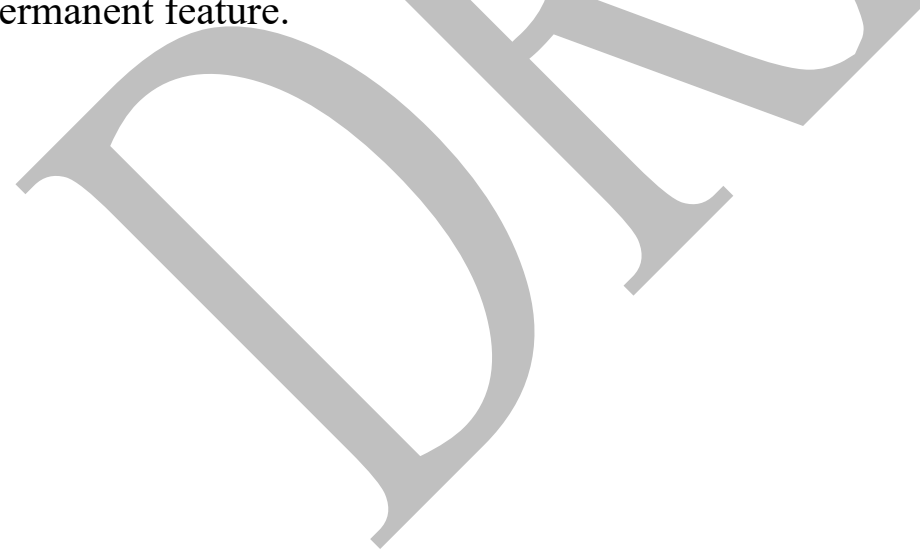

${ }^{123}$ M Khor, 'Rethinking Intellectual Property Rights and TRIPS' in P Drahos and R Mayne (eds), Global Intellectual Property Rights: Knowledge, Access and Development (Palgrave Macmillan 2002) 201-13, 212. 
Email Acceptance Article 3

From: Indira Carr <imcarr@btinternet.com>

Date: Thursday, 30 July 2015 at 10:09

To: Jae Sundaram <jae.sundaram@buckingham.ac.uk>

Subject: Re: Article - Draft

Dear Jae,

Sorry for the delay. Happy to accept the paper. Could you send me a final copy? Just one version sufficient.

Best,

Indira

Sent from my iPad

On 13 Jul 2015, at 11:24, Jae Sundaram <jae.sundaram@buckingham.ac.uk> wrote:

Dear Indira

Many thanks. I can understand, we had an exam senate last week and the new term has started today!

Best

Jae

From: Indira Carr <imcarr@btinternet.com>

Date: Monday, 13 July 2015 11:17

To: Jae Sundaram <jae.sundaram@buckingham.ac.uk>

Subject: Re: Article - Draft

Dear Jae,

I will chase the reviewer today. I suppose exams must have come in the way.

Best,

Indira

Sent from my iPad

On 13 Jul 2015, at 10:56, Jae Sundaram <jae.sundaram@buckingham.ac.uk> wrote:

Dear Indira

I hope you had a pleasant weekend.

Was the article (draft) sent earlier any good? Please let me know.

Best

Jae 
From: Jae Sundaram

Sent: 22 June 2015 15:41

To: Indira carr

Subject: Article - Draft

Dear Indira

Please find attached my first draft of the article entitled Access to Medicines and the TRIPS Agreement: What Next for Sub-Saharan Africa? I have highlighted footnote 20 in red, as I wasn't sure if it is cited properly.

Please note I have attached two documents - one in the regular format and the second one with wider margins.

I hope it meets the standards of ICTL...

Best regards

Jae

University of Buckingham - Leading the National Student Survey since 2006 